\title{
Mycosis Fungoides and Sezary Syndrome N1a TNM Finding v8
}

National Cancer Institute

\section{Source}

National Cancer Institute. Mycosis Fungoides and Sezary Syndrome N1a TNM Finding v8. NCI Thesaurus. Code C141314.

Clone negative. Note: A T-cell clone is defined by polymerase chain reaction (PCR) or Southern blot analysis of the TCR gene. (from AJCC 8th Ed.) 